\title{
The study of the sociospatial aspect of green building in St.Petersburg: theoretical and practical aspects
}

\author{
Tamara Orlovskaya ${ }^{1, *}$ and Svetlana Ershova ${ }^{1}$ \\ ${ }^{1}$ Saint-Petersburg state university of architecture and civil engineering, 190005, 4 2nd \\ Krasnoarmeiskaya St., Saint-Petersburg, Russia
}

\begin{abstract}
The article discusses the modern problems of green building. The duality of the greening problem in large cities is noted: on the one hand, this is one of the factors of conflict, on the other hand, the factor of the quality of life, creativity of the city, and its image level. The selection of factors for the analysis was carried out taking into account the research of Russian and foreign scientists and the possibility of obtaining reliable statistics. The study was conducted according to the landscaping of the districts of St. Petersburg. As a result of the study, clustering of St. Petersburg districts was carried out according to greenery indicators, the level of green construction in each of the considered territories of the city was estimated. A paired analysis of indicators made it possible to identify the most problematic areas of the city, to conduct a comparative assessment of the districts according to the level of greenery and their sufficiency to create a comfortable environment
\end{abstract}

\section{Introduction}

The concepts of livability and quality have become central to current trends in the development of cities and their meaning is constantly and critically re-examined by researchers and practitioners [1,2]. Among other factors that define livability and attractiveness of any city, the quality and quantity of urban greenery and green spaces are the most important and highly valued ones. Green spaces perform not only an important ecological role, serving as a buffer zone between ever-increasing anthropogenic development and natural environment, but cultural functions as well. As claimed by PwC experts [2], an "urban green belt" is a crucial element when considering the brand of the city, and any changes in its structure and quality could have effects on how the city is perceived.

However, significant discrepancies between different definitions and methodological approaches to measuring qualitative and quantitative aspects of urban green spaces require thorough investigation in order to produce any meaningful scientific and applied results. Research by Tulicheva [3], for example, highlights the impact of methodological approaches on the final research results, as well as specifically deals with ecological factors

* Corresponding author: e-tamara@mail.ru 
as a part of measurements of the quality of built environment and strategic planning policies [3]. Analysis conducted by $\mathrm{PwC}[2,4,5]$ considers green spaces as a part of a more broad agenda on residents' health and well-being.

Some researchers are focusing on green spaces as an example of "conflict nodes" of urban development since the development of green urban areas involves multiple stakeholders with diverse interests. Green spaces are, on one hand, a perfect example of a "common good" that benefits all the society by performing recreational functions and having positive effects on well-being and life expectancy of urban residents. On the other hand, green spaces occupy vast parcels of land, which are excluded not only from profit extraction by private developers and businesses but also from urban development policies of road and public amenities construction. As claimed by Pacione [6], the conflict around green areas development tends to occur on the overall city level as well as on the local level.

Having considered these arguments, the author believes that green spaces development should be included on the list of the most "acute conflict nodes of megapolises" as presented by Schtadelbauer [7], and considered as an issue of crucial importance for urban planning research and practice, especially in terms of stakeholder analysis. The authors also suggest, that in order to discover the conflict potential of green area developments, a thorough analysis of worldwide trends in urbanization, residents' experiences and risk zones should be conducted. In this case, fundamental research by George Simmel [8], and "the predecessor of modern urban sociology" Charles Booth [1] should be evaluated. The suggested approach requires green area developments to include social mapping and other methods that will increase our understanding of actual demand for new green area development. This issue remains of critical importance to the urban development of St. Petersburg.

\section{Formulating the problem}

Major urban centers and megapolises are increasingly seen as sites for researchers who are interested in the cutting-edge developments in urbanization processes and new urban phenomena, among which are many trends revolving around urban green areas. This growing interest is closely connected to the establishment of entire body of research on the topics of livability and quality of urban environment [9-11]. A study of green spaces as a distinct type of urban space can also be considered a vital building block on the path to understand current trends in global urban development trends. Recent changes in cities all over the world demonstrate that urban development is gradually becoming a practice that is less preoccupied with developing artificial built environments, and more concerned with finding spaces for connecting natural and artificial habitats of human beings within cities. Seeing this trends as aimed at harmonizing urban development, researchers at PwC [4] claim that developing the city of the future will inevitably entail developing the "Green City" [4]. Researchers also consider the development of green urban spaces as intrinsically connected to rising creativity of cities, i.e. accumulation of creative capital goes hand in hand with increase in livability measured, among other things, as total area of green spaces, as well as number of designated recreational and leisure parks [5]. The amount of green spaces is also included in indices and rankings that measure health and well-being.

Having considered these arguments, authors claim that significant changes have occurred in urban development goals, which are now oriented towards harmonization and humanization of built-up spaces, especially, through continual reexamination of the role of green urban spaces development. In order to enhance strategy of sociospatial development of St.-Petersburg, authors suggest investigating the state of spatial organization of green spaces on a local level (city districts) through field-based methods and techniques [9], 
which will allow researchers to determine weakest spots in green spaces provision and devise areas for prospective green spaces development. The overall goals of proposed approach include analyzing green areas of the city as sources for potential conflict and determining possible risk zones. When full understanding of the distribution patterns of such zones on the local level is reached, only then will it be possible to create detailed map of green areas in order to make beneficial amendments to strategies of socioeconomic and spatial development of St.-Petersburg.

\section{Research design and data collection}

The works of Russian and foreign scientists in the field of studying the conflict potential in global cities [12-14] are the basis of the research. The authors of the article have used the informational and statistical database of Russia in the in Saint-Petersburg and Leningrad Region [15], materials of the Russian and foreign cities studies of PwC [1-2, 4-5, 12, 15]. In order to assess the degree of greening of districts of St.-Petersburg, statistical data on the main indicators of spatial distribution of the following types of public green spaces has been used - gardens, squares, parks and green spaces of a special purpose. The assessment was grounded in the methodological framework of indicators, suggested by $\mathrm{PwC}$ [4]: proportion of green spaces per capita and percentage of green spaces in overall area of the city.

Study of these indicators will ensure further evidence for the hypothesis on the interconnectedness between livability, quality of life, health and well-being of urban residents and sustainable development, which was originally put forward by UN-Habitat [16], PwC [4, 5] and a number of Russian and international scholars [9, 12].

The degree of greening of Saint-Petersburg has been analyzed in the context of administrative districts of the city. The degree of greening in different local areas of the megacity for specific groups of indicators (public green spaces under the supervision of local and city government, street greenery, urban forests) has been analyzed on the basis of indicator normalization by converting the size scale to the dimensionless according to the formula:

$$
X^{\prime} i=(X i-X \min ) /(X \max -X \min )
$$

Where $X_{i}{ }_{i}$ - normalized value of input indicator;

$X_{i}$ - actual value of the indicator;

$X_{\min }$ - the minimum value of the indicator in the sample;

$X_{\max }$ - maximum value of the indicator in the sample.

General scientific methods of learning, methods of logical analysis, expert review and comparative analysis methods have been used in the study.

\section{Main findings and discussion}

According to $[15,16]$ the degree of urban greening is one of most crucial aspect of urban environment that instantly provide evidence of its quality. The need to find balance between objective and subjective indicators when measuring the degree of urban greening represents a major methodological difficulty of measuring it.

In order to aggregate input indicators by means of normalization and transformation, the following absolute variables, which are considered most significant, are suggested to be used [12]:

1. $X_{I}-$ total area of public green spaces under the supervision of city government in ha; 
2. $X_{2}$ - total area of public green spaces under the supervision of municipal councils in ha;

3. $X_{3}$ - total area of street greenery in ha;

4. $X_{4}$ - total area of urban forests.

5. In order to aggregate input indicators by means of normalization and transformation, the following relative variables, which are utilized in research by $\mathrm{PwC}$, are suggested to be used [4, p.33]:

6. $X_{5}$ - proportion of urban green spaces per capita in \%,

7. $X_{6}$ - percentage of urban green spaces in overall area of the city in $\%$.

8. When performing transformation the dimensionless value of input indicator $X_{i}^{\prime}$ changes from 0 (if $X_{i}=X_{\min }$ ) to 1 (if $X_{i}=X_{\max }$ ). The indexes for each territory have been calculated on a cumulative basis.

The index of greening (IoG) for each district of St. Petersburg has been calculated on the summation of normalized dimensionless values of the input indicator $X_{i}^{\prime}$ according to the formula (1) by greening indicator groups (table 1).

Table 1. Cumulative greenery assessment by districts of St. Petersburga .

\begin{tabular}{|c|c|c|c|c|c|}
\hline District & X1 & X2 & X3 & X4 & $\begin{array}{c}\text { The index of } \\
\text { greening (IoG) }\end{array}$ \\
\hline Admiralteyskiy & 0,048 & 0,031 & 0,003 & 0,000 & 0,081 \\
\hline Vasileostrovskiy & 0,042 & 0,228 & 0,090 & 0,000 & 0,360 \\
\hline Vyborgskiy & 0,529 & 0,712 & 0,674 & 0,134 & 2,049 \\
\hline Kalininskiy & 0,367 & 0,589 & 0,750 & 0,000 & 1,706 \\
\hline Kirovskiy & 0,227 & 0,667 & 0,387 & 0,000 & 1,281 \\
\hline Kolpinskiy & 0,163 & 0,126 & 0,351 & 0,035 & 0,675 \\
\hline Krasnogvardeiskiy & 0,132 & 0,528 & 0,719 & 0,000 & 1,379 \\
\hline Krasnoselskiy & 0,455 & 0,473 & 0,678 & 0,003 & 1,608 \\
\hline Kronshtadtskiy & 0,000 & 0,000 & 0,000 & 0,000 & 0,000 \\
\hline Kurortniy & 0,189 & 0,393 & 0,334 & 1,000 & 1,917 \\
\hline Moskovskiy & 0,238 & 0,770 & 1,000 & 0,000 & 2,007 \\
\hline Nevskiy & 0,192 & 1,000 & 0,758 & 0,000 & 1,950 \\
\hline Petrogradskiy & 0,168 & 0,029 & 0,214 & 0,000 & 0,410 \\
\hline Petrodvortsoviy & 1,000 & 0,291 & 0,210 & 0,137 & 1,638 \\
\hline Primorskiy & 0,446 & 0,493 & 0,899 & 0,100 & 1,937 \\
\hline Pushkinskiy & 0,523 & 0,237 & 0,586 & 0,000 & 1,346 \\
\hline Frunzenskiy & 0,201 & 0,690 & 0,601 & 0,000 & 1,492 \\
\hline Centralniy & 0,030 & 0,028 & 0,033 & 0,000 & 0,091 \\
\hline
\end{tabular}

${ }^{\text {a }}$ Based on $[12,14]$.

The territorial and demographical aspect of greening is studied on the basis of relative variables of greening in a particular city district. The density index (DI) is calculated for each district of St. Petersburg as sum of the normalized dimensionless values of the input indicator $X_{i}^{\prime}$ according to formula (1) by the groups of density of greening (table 2). 
Table 2. Cumulative greenery assessment by districts of St. Petersburg ${ }^{\mathrm{a}}$

\begin{tabular}{|c|c|c|c|}
\hline District & X5 & X6 & $\begin{array}{c}\text { The density } \\
\text { index (DI) }\end{array}$ \\
\hline Admiralteyskiy & 0,03 & 0,20 & 0,23 \\
\hline Vasileostrovskiy & 0,03 & 0,20 & 0,23 \\
\hline Vyborgskiy & 0,13 & 1,00 & 1,13 \\
\hline Kalininskiy & 0,08 & 0,73 & 0,81 \\
\hline Kirovskiy & 0,11 & 0,50 & 0,61 \\
\hline Kolpinskiy & 0,11 & 0,17 & 0,28 \\
\hline Krasnogvardeiskiy & 0,05 & 0,18 & 0,23 \\
\hline Krasnoselskiy & 0,15 & 0,34 & 0,48 \\
\hline Kronshtadtskiy & 0,10 & 0,02 & 0,12 \\
\hline Kurortniy & 0,63 & 0,17 & 0,80 \\
\hline Moskovskiy & 0,11 & 0,15 & 0,26 \\
\hline Nevskiy & 0,05 & 0,12 & 0,17 \\
\hline Petrogradskiy & 0,27 & 0,08 & 0,35 \\
\hline Petrodvortsoviy & 1,00 & 0,28 & 1,28 \\
\hline Primorskiy & 0,09 & 0,14 & 0,23 \\
\hline Pushkinskiy & 0,33 & 0,14 & 0,47 \\
\hline Frunzenskiy & 0,08 & 0,03 & 0,11 \\
\hline Centralniy & 0,00 & 0,00 & 0,00 \\
\hline
\end{tabular}

${ }^{\text {a }}$ Based on $[12,14]$.

The results of a paired analysis of green areas and greening densities in the districts of St. Petersburg are given below (table 3 ).

The results of the conjugate analysis of absolute and relative dimensions of greening are shown in table 3.

Table 3. Differentiation of metropolitan areas by the level of greenery (for example, St. Petersburg) ${ }^{\mathrm{a}}$

\begin{tabular}{|c|c|c|c|c|c|}
\hline \multirow{2}{*}{$\begin{array}{l}\text { The } \\
\text { density } \\
\text { index }\end{array}$} & \multicolumn{5}{|c|}{ The index of greening } \\
\hline & $0,00 \div 0,41$ & $\begin{array}{c}0,42 \div 0 \\
, 82\end{array}$ & $\begin{array}{c}0,83 \div \\
1,23\end{array}$ & $1,24 \div 1,64$ & $1,65 \div 2,05$ \\
\hline $0,00 \div 0,26$ & $\begin{array}{c}\text { Admiralteyskiy } \\
\text { Vasileostrovskiy } \\
\text { Kronshtadtskiy } \\
\text { Centralniy }\end{array}$ & & & $\begin{array}{c}\text { Krasnogvardeisk } \\
\text { iy } \\
\text { Frunzenskiy }\end{array}$ & $\begin{array}{l}\text { Moskovskiy Nevskiy } \\
\text { Primorskiy }\end{array}$ \\
\hline $0,27 \div 0,52$ & Petrogradskiy & $\begin{array}{c}\text { Kolpin } \\
\text { skiy }\end{array}$ & & $\begin{array}{c}\text { Krasnoselskiy } \\
\text { Pushkinskiy }\end{array}$ & \\
\hline $0,53 \div 0,78$ & & & & Kirovskiy & \\
\hline $0,79 \div 1,04$ & & & & & $\begin{array}{c}\text { Kalininskiy } \\
\text { Kurortniy }\end{array}$ \\
\hline $1,05 \div 1,30$ & & & & & $\begin{array}{c}\text { Vyborgskiy } \\
\text { Petrodvortsoviy }\end{array}$ \\
\hline
\end{tabular}

${ }^{\text {a }}$ Compiled by [14].

The study of the degree of greening within a framework of socio-spatial aspect involves the study of various groups of indexes. The group of indicators based on the relative measurements of the degree of greening supports the analysis from demographic and 
territorial standpoint. The group of indicators based on absolute measurements of the degree of greening makes possible the understanding of actual state of green space provision of any given territory and describing each territory as more or less green from a quantitative standpoint. The conjugate analysis makes possible to develop an adequate model of greening of any given territory, which in turn will allow providing policy recommendations for priorities of prospective green spaces provision.

\section{Conclusions}

As a result of application of methodological approach that was discussed above, four groups of districts were designated with respect to the degree of greening:

1.the highest degree of greening is present in Moskovskiy, Nevskiy, Primorskiy, Kalininskiy, Kurortniy, Vyborgskiy and Petrodvortsoviy districts of St.-Petersburg (IoG = $1,65-2,05)$;

2.high degree of greening can be found in Krasnogvardeiskiy, Frunzenskiy, Krasnoselskiy, Pushkinskiy and Kirovskiy districts ( $\mathrm{IoG}=1,24-1,64)$;

3. sufficient degree of greening is present in Kolpinskiy district ( $\mathrm{IoG}=0,42-0,82$ );

4. low degree of greening can be found in Admiralteyskiy, Centralniy, Vasileostrovskiy, Kronshtadtskiy and Petrogradskiy districts of St. Petersburg ( $\mathrm{IoG}=0,00-0,41)$.

When analysed from the perspective of density of greening, districts of St. Petersburg form the following five groups:

1.the highest density of greening is observed in Vyborgskiy and Petrodvortsoviy districts (DI = 1,05-1,30);

2. high density of greening is present in Kalininskiy and Kurortniy districts (DI $=0,26-$ $0,90)$

3. average density of greening is present in Kirovskiy district ( $D I=0,53-0,78$ );

4. low density of greening is observed in Petrogradskiy, Kolpinskiy, Krasnoselskiy and Pushkinskiy districts (DI $=0,27-0,52)$;

5.critically insufficient density of greening is present in Admiralteiskiy, Vasileostrovskiy, Kronshtadtskiy, Centralniy, Krasnogvardeiskiy, Frunzenskiy, Moskovskiy, Nevskiy and Primorskiy districts (DI =0,00-0,26).

Performing of conjugate analysis allowed authors to define zones with corresponding values of indices - Admiralteiskiy, Vasileostrovskiy, Kronshtadtskiy, Centralniy (lowest degrees of greening and lowest density of greening); Viborgskiy and Petrodvortsoviy (highest degree and density of greening); Kolpinskiy (low degree of greening and low density of greening).

The conjugated data on the rest of districts of St. Petersburg (Moskovskiy, Nevskiy, Primosrkiy, Krasnogvardeiskiy, Krasnoselskiy, Pushkinskiy, Kirovskiy, Petrogradskiy) remain inconclusive due to significant discrepancies between quantitative dimension of green spaces and present resident population, as well as great differentiation in the percentage of green spaces in the total area of the district.

The article had been prepared as part of the work on the grant of Saint-Petersburg state University of architecture and construction №181/27.06.2019 for implementation of scientific research in the $2019 / 20$ school year under the Program of encouraging young scientists.

\section{References}

1. E. A. Volosnokova, Bull. Tomsk St. Un. Philosoph. Sociol. Polit. Sci. 1 (17), 107-113 (2012) 
2. Megapolis of the future. Space for living. Summary of the study (2018) www.pwc.ru//future-megapolis1.pdf

3. L. D. Tulicheva, ed S. V. Kuznetsov, The use of comparative studies to determine the strategic priorities of regional development, (2007)

4. Health Care Efficiency Study (2018) www.pwc.ru//issledovanie-effectivnostizdravoohraneniya-v-gorodah-mira.pdf

5. Creative capital index of Russian cities. Methodology and research results (2016) www.pwc.ru//CCI_Otchet 01032017.pdf

6. M. Pacione, Urban Geography: a Global Perspective. London, New York (2001)

7. J. Stadelbauer, N. A. Sluka, M. C. Confl. Space Glob. City: Theor. Real. 66-78 (2007)

8. G. Zimmel, Big cities and spiritual life Logos,

http:// magazines.russ.ru/logos/2002/3/zim.html (2002)

9. S. V. Yavon, Azimuth of Scientific Research: Economics and Administration, 7(2), 376-380 (2018)

10. E. G. Animitsa, N. Yu. Vlasova, Ya. P. Silin, ed. A. I. Tatarkin, Urban policy: theory, methodology, practice, (2004)

11. D. E. Andersson, O. E. Anderssson, M. A. Goldberg, ed. V. M. Sereev, The gateway to the global economy translation from English, (2001)

12. S. A. Ershova, Standards of urban design. The experience of St. Petersburg (2014)

13. M. Batty, Model Cities Working Papers, 113, 37 (2007) https://www.bartlett.ucl.ac.uk/casa/publications/working-paper-113

14. Database of municipal indicators, http://www.gks.ru/dbscripts/munst/

15. The struggle for the citizen: Human potential and urban environment (2016).mosurbanforum.ru/files/pdf/analiticheskie_obzory/issledovanie_gorodov.pdf

16. Planning for sustainable cities: strategy directions Global report on human settlements 2009. Abridged version. UN-HABITAT United Nations human settlements programme, https://www.unhabitat.org/grhs/2009 